\title{
AGRIBUSINESS INNOVATION IN FRESHWATER SWAMP THROUGH DEVELOPMENT OF ORGANIC RICE
}

\author{
Muhammad Fauzi \\ Lecturer at the Faculty of Agriculture \\ Lambung Mangkurat University, Banjarbaru, South Kalimantan \\ e-mail : mfauzimakki@gmail.com
}

\begin{abstract}
In the economy of South Kalimantan, the agricultural sector has a significant growth and plays a role as one of the major contributors to the economic structure. However, in some areas with particular land typology like freshwater swamp; it is not reflected in the level of farmers' welfare. In reality, many farming households in freshwater swamp that solely rely on rice farming still live in a poor condition because of low income. It is therefore necessary to find the alternative solutions through agribusiness innovation. Until now freshwater swamp is always identified with non-organic rice or conventional freshwater swamp rice; Alabio livestock, Alabio potato and Swamp buffalo. The purpose of this study was to analyze the potency of freshwater swamp for the welfare of farmers through agribusiness innovation in addition to oil palm plantations. The study was conducted in Teluk Limbung Village, Babirik Subdistrict, Hulu Sungai Utara Regency, by census with 17 farmers as the respondents. The productivity of organic rice in freshwater swamp reached 4.6 tons/ha. The earned income was greater compared to the income when the farmers only grew inorganic rice like what is commonly cultivated by farmers in the swampy lands.
\end{abstract}

Keywords: rice farming, freshwater swamp, productivity, organic rice

\section{INTRODUCTION}

Swampland is a potential agricultural resource, but it has problems because it has a typical typology in terms of soil condition with its diverse fertility and water control (Rois 2011; Ar-Riza and Alihamsyah, 2005; Alihamsyah, 2004). In South Kalimantan, the utilization of freshwater swamp for agriculture is estimated to have been practiced since more than 200 years ago. Based on its formation process, swamplands in South Kalimantan are divided into two groups, tidal swampland and non-tidal swampland or freshwater swamp (Noor; 2004). Freshwater swamp is divided into three zones or three areas, namely: shallow, medium, and deep freshwater swamp (Noor, 2007). The freshwater swamp in South Kalimantan are 153,268 ha (Irianto, 2006). The obstacle in controlling water causes the utilization of freshwater swamp is limited, especially when the land is utilized throughout the year, particularly for rice (Rois, 2011; Rahman, 1992). Not surprisingly, many farmers in freshwater swamp are still poor. Data show that the regency in South Kalimantan with the largest area of freshwater swamp, Hulu Sungai Utara (HSU), is still categorized poor based on the criteria of the Ministry of Regional Development (KPDT) and also became the only regency in South Kalimantan Province categorized poor. However, there is actually more opportunity for the innovation to harness the freshwater swamp for the development of organic rice farming in addition to various other businesses such as fishery sector and livestock of Alabio.

The lifestyle of people as consumers who begin to pay attention to the importance of health and the environment by using organic products make the organic farming is increasingly growing in Indonesia (Mayrowani, 2012; Inawati 2011; Isnaini, 2006). According to Mayrowani (2012) and Ariesusanty et al., (2010); In addition to the continued increase in land areas used for organic farming, Indonesian Organic Alliance also noted the increasing number of producers of organic commodities, as well as different organic commodities, organic trademark, and suppliers to retailers such as super markets and great restaurants. Data of Indonesian Organic Agricultural Statistics in 2010 noted that certified organic producers reached 9,805 . This number is higher than that of uncertified producers, only 3,817 .

\section{MATERIALS AND METHOD}

This study was carried out at an agroecosystem of freshwater swamp in Hulu Sungai Utara (HSU) Regency. The regency has been purposively selected as the description of South Kalimantan's swampy areas on the basis that the regency is the area 
with the most extensive swampy land. Nearly $70 \%$ of HSU Regency is the area of freshwater swamp. Moreover, the farmers are the human resources in agriculture that has the hereditary in managing agricultural businesses in swampy areas. The village was also selected purposively, namely Teluk Limbung Village for the organic rice crops. Primary data were collected through a structured interview with questionnaire to the farmers who cultivated organic rice crops. The development of organic rice was still relatively new so the number of farmers cultivating the crops was also limited, only 17 people in Teluk Limbung village, Babirik sub-district. All those farmers were taken as the respondents in this study.

\section{RESULTS AND DISCUSSION}

\section{Use of Production Inputs}

Farmers plant rice once a year, in accordance with the activity of non-organic rice planting. The farmers in Teluk Limbung village have developed organic rice since 2012. All the observed farmers were previously non-organic rice farmers. The cultivated land was also the land that had been used for non-organic rice planting. However, the residue of fertilizer input that could still remain mainly due to the management of non-organic rice was low because the use of artificial fertilizers in the freshwater swamp was still minimum as the farmers used fertilizers only in nursery stage.

The treatment for organic rice crops in freshwater swamp did not differ from the cultivation typically done in non-organic rice cultivation. Land preparation started when the water in the swampy rice fields subsided or rainy season came to an end and the dry season began. Most farmers in the research site still take into account the natural phenomena, such as stargazing in conjunction with forecasting drought or rainy season. For example, the sight of 'baur bilah' stars that appear on the western horizon lined three forming straight lines which indicates dry season (Noor, 2007). However, the groups of farmers in Teluk Limbung also began utilizing BMKG information for the climate. The principle of the soil tillage in swampy areas is only intended to remove grasses or aquatic vegetation that grow after the previous harvest season by pulling, cutting, or scraping the grasses, weeds and aquatic vegetation, and only a few layers of soil participate are peeled (less than 5-8 cm).

Rice crops cultivated by organic farmers in swampy areas generally were in a category of watun I (shallow) using the certified seeds of varieties from Seed Center in Malang. Different harvesting age of this variety is relatively the same as the nonorganic varieties, about 3.5 to 4 months. One of the constraints on the use of these seeds is the price and availability because one indicator of organic rice is the use of certified organic seeds. Initial seedbed was performed over the dikes. The number of seeds sown for one hectare was approximately $35-41 \mathrm{~kg}$. The data of the study show that the farmers in the study sites used seeds at an average of $38.6 \mathrm{~kg}$ per hectare. Fertilizer given during the nursery was compost with an average dose of $126 \mathrm{~kg}$ per hectare. There were also some farmers who used liquid organic fertilizer. The other input used in the organic rice farming was the use of botanical pesticides.

Table 1 show the number of production inputs for organic rice farming and its comparison to those used by the farmers in Teluk Limbung for non-organic rice. 
Table 1. Average Use of Inputs per ha

\begin{tabular}{lccc}
\hline \multirow{2}{*}{ Type of Input } & \begin{tabular}{c} 
Non-organic rice \\
\cline { 2 - 4 }
\end{tabular} & $\begin{array}{c}\text { Organic rice } \\
\text { (Year 1) }\end{array}$ & $\begin{array}{c}\text { Organic rice } \\
\text { (Year 3) }\end{array}$ \\
\hline Seed $(\mathrm{kg})$ & $\begin{array}{c}\text { 17) land width } \\
\text { of } 6 \text { ha }\end{array}$ & $\begin{array}{c}(\mathrm{N}=6) \text { land width of } \\
2 \text { ha }\end{array}$ & $\begin{array}{c}(\mathrm{N}=17) \text { land width } \\
\text { of 6 ha }\end{array}$ \\
Organic Pesticide (It) & 34.2 & 40.30 & 38.6 \\
Chemical Pesticide (It) & 0.00 & 1.2 & 1.8 \\
Compost/Manure Fertilizer $(\mathrm{kg})$ & 2.35 & 0.00 & 0.00 \\
Urea (kg) & 0.00 & 294 & 356 \\
Liquid organic fertilizer & 34 & 0 & 0 \\
TKDK (HOK) & 0 & 0 & 2.1 \\
TKLK (HOK) & 158 & 162 & 164 \\
\hline
\end{tabular}

Note: The comparison of the inputs was performed by assessing the number of inputs used by the same farmers when cultivating non-organic rice and organic rice

\section{Production and Farmer Income}

The productivity of organic rice (organic brown rice) in freshwater swamp based on the calculation was about 10 Belik (8-12 Belik) per borong. If one belik is equivalent to $12.5 \mathrm{~kg}$ and 1 ha is 35 borong, the productivity of organic rice in the freshwater swamp reaches 4.6 tons/ha. However, in the first year, the rice production was still relatively low at only 4 tons per ha. The average production of organic rice in year 3 was higher than the production of nonorganic rice Ciherang which only produced an average yield of 4.3 tons per ha. Data from this study showed lower production when compared with data of non-organic rice production released by the HSU Regency Agricultural Office, the average productivity of non-organic rice ranged between 5.5 tons - 5.8 tons per hectare.

This difference is due to different sampling where the Agriculture Office of HSU Regency used a tile system, taking the harvest yield from the size of $2 \times 2$ meters or $3 \times 3$ meters in paddy fields. After counted, the results were then multiplied by the existing acreage. Normally in doing tile, lots were drawn from the field with very high yield. In this study, the data were based on the information from farmer respondents that was then validated with the harvest yield and width of planted area. It did not use a tile system.

The results of this study were different from the research conducted by Prayoga (2010) which stated that the productivity of organic rice in the first two years will be below the productivity of inorganic rice (planting rice using chemical fertilizers and pesticides) and only after entering the third year it would be equal and so exceeded productivity non-organic rice. The comparison between non-organic rice and organic rice in a single stretch in some previous studies was carried out using the approach of total factor productivity (TFP). TFP measured the ability of all kinds of production factors as the aggregate production unit in producing the output (Chamber, 1988).

This measure in the form of an index which is the quotient of the output quantity index toward input quantity index. The index value of TFP generally indicated that the organic rice after the third year up to the fifth would be more efficient and profitable than nonorganic rice because the level of overall input use would get reduced compared to the level of output achieved so the organic rice after the third and fifth year would be more productive compared to non-organic rice. It was also proved in the freshwater swamp.

Prices for farmers in the form of packaging could reach $\mathrm{Rp} 13,000$ - 15,000 per $\mathrm{kg}$ so that the farmers' gross income was $\mathrm{Rp}$ 59.8 million - Rp 69 million per hectare. This gross income was much greater when compared to the gross income if the farmers only cultivated non-organic rice crops. These results are also in line with the results of several other studies such as the studies by Prayoga (2010) and Mayrowani et al. (2010) in Sragen, and Trisanti (2002) in Klaten Regency. Table 2 shows the comparison between organic and non-organic rice in freshwater swamp. 
Table 2. Income Comparison between non-organic rice farming and organic rice farming in freshwater swamp

\begin{tabular}{cccccccccc}
\hline \multicolumn{3}{c}{ Non-organic rice farming per ha } & & \multicolumn{3}{c}{ Organic rice farming per ha } \\
\cline { 1 - 1 } $\begin{array}{c}\text { Production } \\
(\mathrm{kg})\end{array}$ & $\begin{array}{c}\text { Price } \\
(\mathrm{Rp} / \mathrm{kg})\end{array}$ & $\begin{array}{c}\text { Revenue } \\
(\mathrm{Rp})\end{array}$ & $\begin{array}{c}\text { Income } \\
(\mathrm{Rp})\end{array}$ & & $\begin{array}{c}\text { Production } \\
(\mathrm{kg})\end{array}$ & $\begin{array}{c}\text { Revenue } \\
(\mathrm{Rp})\end{array}$ & $\begin{array}{c}\text { Income } \\
(\mathrm{Rp})\end{array}$ \\
\hline 4,300 & 3,446 & $14,817,800$ & $7,037,800$ & & 4,600 & $59,800,000$ & $34,100,000$ \\
\hline
\end{tabular}

RCR non-organic rice crops : 1.90

RCR organic rice crops : 2.33

Constraints faced by farmers were the supporting agronomic components, such as seed availability. The farmers still bought seeds from Malang, East Java, or South Kalimantan or from Seed Center with subsidized prices. In agribusiness innovations, the obstacles were that the demand was still relatively small and the marketing was limited. Therefore, the development of organic rice farming in freshwater swamp in South Kalimantan for three years was only 6 ha. However, along with the high returns that the farmers have gained, the demand for organic rice in South Kalimantan that is expected to increase, and the improvement in agribusiness innovation, the prospects of organic rice-based agribusiness development, especially organic brown rice in freshwater swamp will become better.

\section{CONCLUSION}

The alternative increase in the income of the farm households in freshwater swamp can be developed through agribusiness innovation. There are opportunities of commodities in the freshwater swamp when it is developed based on the principles of sustainable non oil agribusiness system, that is the development of organic rice crops (organic brown rice). In the future, the system of environmentally sustainable agribusiness will become the decisive factor or "passport" to welfare. However, the development of organic rice seeds is still facing some obstacles in the areas of seed supply and marketing coverage.

\section{REFERENCES}

Abdurrahman (1992). Efficiency Analysis of Rice Farming in Freshwater swamp, Hulu Sungai Utara, South Kalimantan. Thesis. The Graduate
School of Gadjah Mada University. Yogyakarta.

Alihamsyah, T. (2004). Potency and Utilization of Swamplands to Increase Rice Production. Economic of Paddy and Rice in Kasyrino Faisal, Effendi Pasandaran and A.M. Fagi (Editors). Agency for Agricultural Research and Develpment, Jakarta.

Ariesusanty, L., S. Nuryanti, and R. Wangsa (2010). Statistics of Organic Agriculture in Indonesia. AOI. Bogor.

Ar-Riza and Alihamsyah, T. (2005). Optimization of Swampland Use in the Development of Rice. Main Paper. Proceedings of the National Seminar on Technological Innovation in Wetland Resource Management and Environmental Pollution Control. Center of Research and Development of Soil and Agro-climate. Banjarbaru.

Inawati, L. (2011). Quality Manager and Market Access of Indonesian Organic Alliance (AOI), workshop "Advancing Organic Agriculture in Indonesia: Opportunities and Challenges". Yayasan Bina Sarana Bhakti in Cisarua, Bogor, West Java $(14 / 3 / 2011)$.

Irianto, G. (2006). "Policies and Water Management in the Development of Freshwater swamp" in M. Noor et al. (eds). Proceedings of National Seminar on Integrated Management of Freshwater swamp; 28-29 July 2006. Balittra Banjarbaru.

Isnaini, M. (2006). Organic Farming for Economic Gain and Earth Sustainability. Kreasi Kencana Publisher Yogyakarta. 
Marliati (2008). Empowerment of Farmers to Fulfill Development Capacity and Independence of Agrobusiness Farmers (A Case in Kampar Regency of Riau Province). Dissertation. Graduate Program at IPB. Bogor.

Mayrowani, H. (2012). Development of Organic Agriculture in Indonesia. Research Forum of Agroeconomy. Volume 30 No. 2, Desember 2012 : 91-108

Mayrowani, H., Supriyati, and T. Sugino (2010). Analysis of Organic Rice Farming in Sragen Regency. Research Report. JIRCAS.

Noor, M. (2007). Freshwater swamp. Ecology, Utilization and Development. Rajawali Pers publisher. Jakarta.

Norginayuwati and Rafieq A. (2007). Local Culture Wisdom in Utilization of Freshwater swamp for Agriculture in South Kalimantan. Indonesian Agency for Agricultural Research and Development. Swamp Land Agricultural Research Center. Banjarbaru.

Prayoga, A. (2010). Analysis of Productivity, Technical Efficiency, and Income of Organic Rice Farming, as well as Level of Implimentation of Organic Lowland Rice Farming (A Case in Sukorejo and Jambeyan Villages, Sambirejo Sub-districts, Sragen Regency). Dissertation. Graduate Program, Brawijaya University. Malang.

Rois (2011). Model of Freshwater swamp Management on the Basis of Local Resources to Develop Sustainable Farming (A Study in Sungai Raya and Sungai Ambawang Subdistricts, Kubu Raya Regency West Kalimantan). Dissertation. Graduate School of IPB. Bogor.

Trisanti, E. (2002). Income Analysis of Organic Rice Farmers in Delanggu Sub-district, Klaten Regency. JDSE Vol. 3 No. 1 June 2002. 